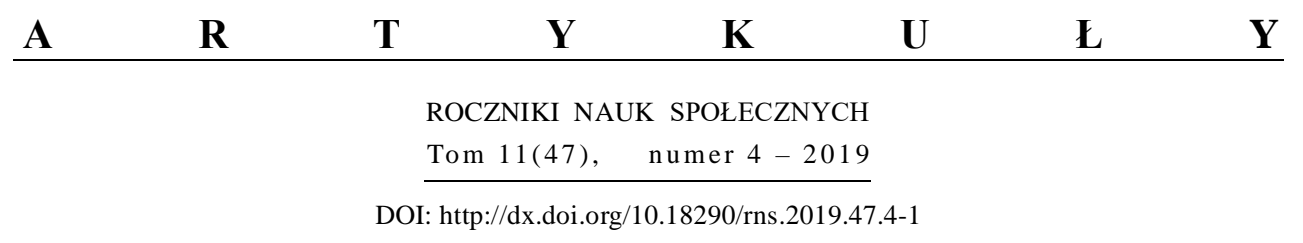

ANIELA DYLUS

\title{
TRUDNY ZWIĄZEK DEMOKRACJI I WOLNEGO RYNKU W WARUNKACH DEGLOBALIZACJI PERSPEKTYWA KATOLICKIEJ NAUKI SPOŁECZNEJ
}

\section{WPROWADZENIE}

Problem wyrażony tytułowym sformułowaniem jest dość skomplikowany i wielowątkowy. Zostanie tu zatem zaprezentowany jedynie w bardzo ogólnych zarysach. Generalnie podejmując go, próbujemy odnieść się do pewnych obserwowanych dziś światowych trendów w obszarach gospodarki, polityki, społeczeństwa i kultury. W związku z negatywnymi skutkami gospodarczej globalizacji, ,powrotem państwa” i kryzysem liberalnej demokracji rodzi się mianowicie pytanie, czy przyjmowana od czasów oświecenia jako pewnik teza o koniunkcji demokracji i wolnego rynku obowiązuje także w warunkach nazwanych umownie „deglobalizacją”. Od dawna znane są przykłady kwitnących w warunkach dyktatury gospodarek rynkowych, np. w Chile pod rządami Augusto Pinocheta czy w Chinach od lat 70. XX wieku. Taką koniunkcję autorytarnych reżimów politycznych z liberalnym systemem gospodarczym traktowano dotąd jako wyjątki od reguły. Czy jednak nasilenie podobnych tendencji w drugiej dekadzie XXI wieku, czyli wzrost liczby wyjątków, nie sygnalizuje już konieczności zmiany paradygmatu, jak powiedziałby Thomas Kuhn? ${ }^{1} \mathrm{Na}$ osłabiony dziś związek demokracji i wolnego rynku chcemy przy tym spojrzeć z ,perspektywy katolickiej nauki społecznej”. Nawet jeśli „deglobalizacja” nie jest wprost przedmio-

Prof. dr hab. ANIELA DYLus - em. profesor UKSW; adres do korespondencji: ul. Modzelewskiego 58 A m. 109, 02-679 Warszawa; e-mail: a.d@wp.pl

${ }^{1}$ Wprawdzie jego teoria rewolucji naukowych dotyczy nauk przyrodniczych (por. T. S. KuHN, Struktura rewolucji naukowych, Warszawa: PWN 1968), ale przez analogię możemy ją odnieść i do nauk społecznych. 
tem uwagi w nauczaniu społecznym Kościoła, to mnóstwo pośrednich odniesień do problemów sygnalizowanych tytułowym sformułowaniem legitymizuje zasadność zaproponowanego tematu.

Na początku tych rozważań niezbędne jest krótkie repetytorium wyjściowej tezy o fundamentalnym związku demokracji i wolnego rynku (1). Pokazane zostanie dalej narastanie kryzysu „demokratycznego kapitalizmu” (2), a następnie losy tego związku w warunkach globalizacji. Wyakcentowane zostaną przy tym te przemiany gospodarcze, które w konsekwencji osłabiają demokrację (3). $\mathrm{Z}$ kolei rezultatem społecznego niezadowolenia z przemian kojarzonych z globalizacją są próby zahamowania globalizacyjnej dynamiki. Pojawia się jednak pytanie, czy w ogóle jest to możliwe (4). Dopiero po uchyleniu tej wątpliwości można podjąć próbę charakterystyki symptomów deglobalizacji (5). Jeśli gospodarczą globalizację cechuje maksimum rynkowej wolności, to z deglobalizacją wiążemy jej ograniczenie. Warto jednak zapytać, czy to osłabienie rynkowej wolności oznacza jednocześnie ograniczenie demokracji (6).

\section{ZWIĄZEK DEMOKRACJI I WOLNEGO RYNKU - KRÓTKIE REPETYTORIUM}

W oświeceniowym katalogu idei, którymi została naznaczona cywilizacja zachodnia: europejska i północnoamerykańska i dzięki którym - jak wierzono ludzkość zostanie wyprowadzona z mroku przesądów i tradycji do światła postępu, obok rozumu, nauki i techniki znajdujemy też wolny rynek i demokrację ${ }^{2}$. Te dwie ostatnie zazwyczaj idą w parze.

Fundamentem obydwu jest bowiem wolność. W obszarze rynku chodzi o wolną przedsiębiorczość, swobodny wybór zawodu i miejsca pracy, wolność zawierania umów i wolną konkurencję, wolny handel i wiele innych swobód ekonomicznych. O wolnościowych zasobach demokracji napisano już całe tomy. Również Jan Paweł II syntetycznie uzasadniając, dlaczego „Kościół docenia demokrację", wskazuje właśnie na tę wartość. Jego odpowiedź: bo odpowiada ona wolności człowieka i chroni jego prawa, bodaj najlepiej streszcza nauczanie społeczne w tej kwestii. Ta wolność manifestuje się przez uczestnictwo. Demokracja została zatem doceniona, „bo zapewnia udział obywateli w decyzjach politycznych”, „,bo gwarantuje możliwość wyboru [...] własnych rządów”, kon-

\footnotetext{
2 Por. U. Di FABIO, Kein Oswald Spengler. Samuel Huntington und der „Clash of Civilisations “, „Die Politische Meinung“" 2017, z. 547, s. 47.
} 
trolowanie ich, a gdy trzeba - „zastępowanie ich w sposób pokojowy innymi” (Centesimus annus - CA 46) ${ }^{3}$.

Wydawało się zatem czymś oczywistym, że wolności rynkowe - kupieckie i wolności obywatelskie wzajemnie się wspierają ${ }^{4}$. W połowie XX wieku Seymour M. Lipset pisał, że „demokracja pozostaje w związku z rozwojem ekonomicznym; im bardziej zamożny jest dany naród, tym większe jest prawdopodobieństwo tego, że panują w nim demokratyczne stosunki”.5. Można przy tym zakładać, że ową zamożność Lipset kojarzył z wolnym, kapitalistycznym systemem gospodarczym. Dobrym przykładem potwierdzającym tę zależność jest model społecznej gospodarki rynkowej, oparty na próbie pogodzenia „wody z ogniem”, czyli wolności ze społeczną równością. Sukces „kapitalizmu nadreńskiego" niewątpliwie był ogromnym wkładem do stabilizacji w Europie demokracji po II wojnie światowej ${ }^{6}$. Nic dziwnego, że właśnie ten system, realizowany „w niektórych krajach”, spotkał się z aprobatą Jana Pawła II (por. CA 19) ${ }^{7}$.

Teza o interdependencji demokracji i wolnego rynku przeżywała swój renesans w okresie implozji systemu komunistycznego po 1989 r. Stanowiła nić przewodnią m.in. koncepcji opracowanej przez Michaela Novaka. Opisywany przez niego Duch demokratycznego kapitalizmu ${ }^{8}$ zawładnął umysłami wielu przedstawicieli elit naszego regionu. Zresztą już dużo wcześniej poniekąd na zasadzie zaprzeczenia doświadczaliśmy obowiązywalności tezy o związku wolności politycznej i wolności gospodarczej. Naocznie okazywało się, że tzw. dyktatura proletariatu jest wszechogarniająca. Nie znosi wyłomów. Opresyjny system monopartyjny idzie w parze $\mathrm{z}$ centralnym sterowaniem gospodarki, a śmiertelnym wrogiem obydwu są: niepokorne myślenie, wolne media i otwarte społe-

\footnotetext{
${ }^{3}$ Kościół nie jest oczywiście bezkrytyczny wobec demokracji. Formułuje wobec niej różne zastrzeżenia i określa warunki właściwego funkcjonowania. Por. np. Centesimus annus 46, Evangelium vitae 56.

${ }^{4} \mathrm{~W}$ niektórych fragmentach tych rozważań nawiązuję do: A. Dylus, Koniunkcja demokracji i gospodarki? Perspektywa „Centesimus annus”, „Chrześcijaństwo - Świat - Polityka” 2017, nr 21, s. 76-93.

${ }^{5}$ Cyt. za: J. SzTUMSKI, Szanse i zagrożenia demokracji $w$ XXI wieku, w: Demokracja $w$ dobie globalizacji, t. II: Aspekty teoretyczne, red. M. Domagała, J. Iwanek, Katowice: Wydawnictwo Uniwersytetu Śląskiego 2008, s. 132. Sztumski uważa, że myśl ta „wyrażona w czasach «zimnej wojny» była raczej przejawem pewnej ideologii niż krytycznej analizy ekonomicznych uwarunkowań demokracji” (tamże).

${ }^{6}$ Przypomniała to Ingeborg GABRIEL, por. Erosion der Demokratie? Eine Problemanzeige, Köln: J.P. Bachem Medien 2012 („Kirche und Gesellschaft“ Nr. 394), s. 9.

${ }^{7}$ Wprawdzie nie ma tu mowy expressis verbis o społecznej gospodarce rynkowej, ale charakterystyka akceptowanego ustroju gospodarczego pozwala na taki właśnie wniosek.

${ }^{8}$ Por. M. NovaK, Duch demokratycznego kapitalizmu, Poznań: Wydawnictwo W drodze 2001. Wydany w 1982 r. The Spirit of Democratic Capitalism lub jego drugie wydanie z 1991 r. było w Polsce znane już wcześniej.
} 
czeństwo. Po załamaniu się tego systemu w 1989 r., czymś oczywistym wydawał się więc wybór „demokratycznego kapitalizmu”.

Zresztą dla wielu przedstawicieli nauk społecznych, jak na przykład dla Harolda Jamesa, „kluczowy wniosek” wysnuty z upadku gospodarek komunistycznych brzmi podobnie: obszary polityczny i ładu gospodarczego są wzajemnie powiązane. „Wydajność gospodarcza zależy od funkcjonującego społeczeństwa obywatelskiego, od rządów prawa i poszanowania własności prywatnej"9. Trudno wreszcie w tym miejscu nie wspomnieć o niezwykle popularnej w latach 90., ale od początku gwałtownie kontestowanej tezie Francisa Fukuyamy o „końcu historii”"10, który rzekomo nastąpił wraz z załamaniem się komunizmu. Gwarantujące wieczny pokój zwycięstwo liberalnej demokracji i gospodarki rynkowej wcale nie było przy tym przypadkowe. Było raczej konsekwencją systemowej przewagi. Kapitalizm okazał się silniejszym systemem gospodarczym, zdolnym do większych osiągnięć. Tym bardziej że związał się z demokratycznym państwem prawa, które najlepiej zabezpiecza przesłanki dla jego rozkwitu, tj. prawa wolnościowe, partycypację i odpowiedzialne rządy ${ }^{11}$.

Zdecydowanie ostrożniej na interesujący nas temat wypowiadał się Samuel Huntington w klasycznej już pozycji z 1991 r. Trzecia fala demokratyzacji. W długiej liście zmiennych branych pod uwagę przy wyjaśnianiu demokracji i demokratyzacji na pierwszych miejscach znalazły się takie czynniki, jak: „wysoki poziom ogólnego dobrobytu” i ,gospodarka rynkowa”. Niemniej mając na uwadze demokratyzację takich krajów jak np. Indie, Kostaryka, Wenezuela, Turcja, Brazylia, Botswana, Grecja, Japonia, która miała miejsce w połowie XX wieku, czyli w czasie, kiedy niektóre $\mathrm{z}$ nich zmagały się z kwestią skrajnego ubóstwa, trzeba zrelatywizować znaczenie w/w czynników gospodarczych. W każdym razie wielość doświadczeń historycznych upoważnia do akceptacji twierdzenia Huntingtona: ,żaden pojedynczy czynnik nie wystarcza, aby wyjaśnić rozwój demokracji we wszystkich krajach - lub tylko w jednym kraju". Znaczy to, że „w każdym przypadku demokratyzacja jest rezultatem splotu różnych przyczyn" ". Próbując wyjaśnić trzecią falę demokratyzacji - z lat 70. i 80. oraz jej drugą fazę (po 1989 r.), autor ten słusznie zauważa: „Jakkolwiek czynniki ekonomiczne mają duże znaczenie, nie są one decydujące" ${ }^{13}$. Stosunkowo

\footnotetext{
${ }^{9}$ H. JAMES, Koniec globalizacji. Czego nauczyt nas wielki kryzys?, Warszawa: Wydawnictwo Naukowe Scholar 2010, s. 292.

${ }^{10}$ Por. F. FukuYama, The End of History and the Last Man, New York: Free Press 1992.

${ }^{11}$ Tak koncepcję Fukuyamy omawia Alexander BRAKEL, por. Nicht so simpel! Francis Fukuyamas ,Ende der Geschichte”, „Die Politische Meinung“ 2017, z. 547, s. 62-63.

${ }^{12}$ S. Huntington, Trzecia fala demokratyzacji, w: Elity, demokracja, wybory, oprac. J. Szczupaczyński, Warszawa: Wydawnictwo Naukowe Scholar 1993, s. 57-58.

${ }^{13}$ Tamże, s. 66.
} 
wysoki poziom PKB w Czechosłowacji i NRD w połowie lat 70. nie miał wówczas wpływu na osłabienie politycznej dyktatury. To samo dotyczy takich krajów jak Arabia Saudyjska, Libia, Kuwejt ${ }^{14}$.

Co ciekawe, w podobnym kierunku idą analizy zawarte w encyklice Centesimus annus. Papież z aprobatą konstatuje wyłonienie się po 1989 r. „,nowych form demokracji" - i to mimo zrujnowanych gospodarek (CA 22). I Huntington, i Jan Paweł II zgodnie stwierdzają, że trudności gospodarcze są tylko jedną z wielu przyczyn upadku „systemów ucisku”. Huntington zwraca uwagę, że gospodarcza mizeria osłabia autorytarne reżimy, zaś dla autora Centesimus annus „decydującym czynnikiem” implozji systemu było „pogwałcenie praw pracy” (CA 23). „Niesprawność systemu gospodarczego” uznaje wprawdzie jako „drugi czynnik kryzysu", ale zaraz dodaje, że jest to raczej następstwo naruszenia praw człowieka: do inicjatywy, do własności, do wolności ekonomicznej. W końcu zaś „prawdziwą przyczyną” cudownych wydarzeń roku 1989 była „pustka duchowa wytworzona przez ateizm" (CA 24). Wszystko to musiało wywołać reakcję. Odkrywanie na nowo własnej tożsamości, sensu życia, religijnych korzeni kultury narodowej, a w końcu samej osoby Chrystusa (CA 24) tkwiło u podstaw wydarzeń roku 1989.

Oczywista jeszcze niedawno teza o koincydencji demokracji i kapitalizmu, ostrożnie formułowana przez politologów, pośrednio obecna także w CA - choć przy innym rozłożeniu akcentów, a powszechnie przyjmowana po upadku komunizmu, chociażby w Polsce, po ćwierćwieczu coraz częściej bywa kontestowana. Dlaczego?

\section{KRYZYS KONCEPCJI DEMOKRATYCZNEGO KAPITALIZMU}

Wiarę w powszechną ważność omawianej tu koncepcji naruszają najpierw coraz liczniejsze od niej wyjątki. Przede wszystkim niedemokratyczne Chiny, gdzie permanentnie łamie się prawa człowieka, urosły do drugiej potęgi gospodarczej świata. Okazało się, że kraj bazujący na tzw. wartościach azjatyckich: wspólnotowości, harmonii, hierarchii społecznej, zaczerpniętych po części z ideologii komunistycznej, a po części z tradycji konfucjanizmu, w ciągu kilku dekad dokonał bezprzykładnego skoku cywilizacyjnego, bez porzucania opresyjnego systemu politycznego ${ }^{15}$. W kilku innych państwach, chociażby w Azji Południowo-Wschodniej czy we wspomnianym już Chile, z powodzeniem łączy się

\footnotetext{
${ }^{14}$ Por. tamże, s. 68-69.

15 Por. A. Smolar, [wypowiedź nt.] Demokracja i kryzys, „Zarządzanie Publiczne” 2011, nr 16-17(2-3), s. 92-94.
} 
dyktaturę (często - wojskową) z liberalnym systemem gospodarczym, co przynosi znaczące sukcesy ekonomiczne. Uważa się, że nawet w Polsce żaden w pełni demokratyczny parlament nie wyraziłby zgody na tak radykalną liberalizację gospodarki, jaką zainicjował Leszek Balcerowicz pakietem dziesięciu ustaw, które weszły w życie 1 stycznia $1990 \mathrm{r}$.

W każdym razie teza o związku demokracji i wolnego rynku jest dziś mniej oczywista niż pod koniec XX wieku. Przyjmując ją jako pewnik zapomina się często, że obydwa zestawiane ze sobą człony mają niezwykle dynamiczny charakter. Nie ma tylko jednego, ponadczasowego modelu rynkowego - kapitalizmu. Podobnie też nie ma wyłącznie jednego modelu demokracji. Podczas gdy wczesny wolnokonkurencyjny kapitalizm rzeczywiście sprzyjał rozwojowi demokracji liberalnej, to niekoniecznie dotyczy to kapitalizmu monopolistycznego ${ }^{16}$. Co więcej, zapewne z wielu względów „demokratyczny kapitalizm” utracił dziś siłę przyciągania, przestał być atrakcyjnym ideałem. Powodów tego stanu rzeczy można się doszukiwać i po stronie demokracji, i po stronie kapitalistycznej gospodarki.

Nie trzeba tu udowadniać tezy o marnej kondycji współczesnej demokracji. Generalnie dominuje dziś sceptycyzm i co do status quo, i co do przyszłości demokracji. Niekiedy przybiera on nawet formę rezygnacji i zupełnego braku złudzeń co do demokratycznych zasobów współczesności oraz obywatelskiej gotowości do uczestnictwa $\mathrm{w}$ decyzjach politycznych ${ }^{17}$. Ten stan świadomości społecznej, ale i analiza kondycji demokratycznego ustroju znajduje wyraz w wielu publikacjach naukowych. Już ich tytuły sygnalizują kryzysową sytuację. Oto wybrane przykłady: Krucha demokracja ${ }^{18}$, Rozstrojona demokracja ${ }^{19}$, Niemoralna demokracja ${ }^{20}$, Demokracja peryferii ${ }^{21}$, Dylematy demokracji $i^{22}$, Erozja demokracji ${ }^{23}$, Postdemokracja ${ }^{24}$, Koniec demokracji ${ }^{25}$.

16 Zwraca na to uwagę m.in. Janusz SzTUMSKI, por. Szanse i zagrożenia demokracji, s. $133-134$.

${ }^{17}$ Por. J. FRÜHBAUER, Wirtschaftsdemokratie. Sichtung eines programmatischen Begriffs, Köln: J.P. Bachem Medien 2013 („Kirche und Gesellschaft“ Nr. 400).

18 Por. Die fragile Demokratie - The Fragility of Democracy, Hrsg. A. Rauscher, Berlin: Duncker \& Humblot 2007.

19 Por. Die verstimmte Demokratie. Moderne Volksherrschaft zwischen Aufbruch und Frustration, Hrsg. S. Braun, A. Geisler, Wiesbaden: VS Verlag für Sozialwissenschaften 2012.

${ }^{20}$ Por. Z. STAwrowski, Niemoralna demokracja, Kraków: Wydawnictwo Ośrodek Myśli Politycznej, Wyższa Szkoła Europejska im. Józefa Tischnera 2008.

${ }^{21}$ Por. Z. KRASNODĘBSKI, Demokracja peryferii, Gdańsk: słowo / obraz terytoria 2003.

${ }^{22}$ Por. A. ZwolińsKi, Dylematy demokracji, Kraków: WAM 2010.

${ }^{23}$ Por. I. GABRIEL, Erosion der Demokratie?

${ }^{24}$ Por. C. Crouch, Postdemokratie, Frankfurt a. M.: Suhrkamp 2008.

25 Por. J.-M. GuÉHENNO, Das Ende der Demokratie, München-Zürich: Artemis \& Winkler 1994; U. Thielmann, Das Ende der Demokratie, „Wirtschaftsdienst“ 12(2011), s. 820-823. 
Spróbujmy tu zapytać o gospodarczy kontekst tego stanu rzeczy. Czy i w jakim sensie gospodarcze przemiany ostatniego ćwierćwiecza były jednym z czynników „odpływu demokracji” (jak powiedziałby Huntington)? Wydaje się, że wskazać tu trzeba przede wszystkim na dwa związane ze sobą zjawiska, tj. procesy globalizacji ${ }^{26}$ i rozpoczęty w 2007 r. światowy kryzys gospodarczy, oraz na wielorakie osłabiające demokrację konsekwencje tych fenomenów. Zasługują one na odrębne potraktowanie.

\section{PRZEMIANY GOSPODARCZE OSŁABIAJĄCE DEMOKRACJĘ W WARUNKACH GLOBALIZACJI}

Zgubne dla demokracji skutki globalizacji gospodarczej w całej pełni ujawniły się na przełomie wieków i w pierwszych dekadach obecnego stulecia. Chodzi tu m.in. o utratę prymatu polityki nad gospodarką. W analizach procesu globalizacji powtarza się konstatacja, że napędzana rewolucją elektroniczną dynamika globalizacyjnych przemian w gospodarce znacznie wyprzedza przemiany polityczne. Tym bardziej że towarzyszyła im ideologia globalizmu, zgodnie z którą zderegulowane rynki najlepiej służą wzrostowi dobrobytu ${ }^{27}$. Na niebezpieczeństwo rozpowszechniania się takiej „radykalnej ideologii kapitalizmu” z jej „Ślepą wiarą", że wszelkie problemy społeczne, np. skrajnej nędzy materialnej, rozwiąże „swobodna gra sił rynkowych”, wskazywał już Jan Paweł II (CA 42). Po ponad ćwierćwieczu również papież Franciszek w adhortacji Evangelii Gaudium (EG) z pasją polemizował z ideologią ,,absolutnej autonomii rynków" (EG 56). Dowodził, że nie da się obronić tzw. teorii skapywania (trickle down theory) zakładającej, że w warunkach autonomii rynkowej długofalowo ze wzrostu gospodarczego automatycznie korzystają wszyscy. Przy takim założeniu zbędne są oczywiście wszelkie przedsięwzięcia państwa z zakresu polityki gospodarczej czy społecznej. Papież odsłania ideologiczny charakter tej teorii „nigdy nie potwierdzonej przez fakty" (EG 54).

\footnotetext{
${ }^{26} \mathrm{Na}$ zagrożenia demokracji związane z globalizacją wskazuje wielu autorów. Oprócz dzieł już cytowanych por. także: Globalisierung und Demokratie. Wirtschaft, Recht, Medien, Hrsg. H. Brunkhorst, M. Kettner, Frankfurt a. M.: suhrkamp taschenbuch 2000; Globalisierung und Demokratie, Hrsg. A. Habisch, M. Hartmann, S. Schmidt, J. Wieland, Münster-Hamburg-London: LIT 2000; E. POLAK, Globalizacja a zagrożenia dla demokracji, w: Demokracja w dobie globalizacji, s. 140-153; M. JAROSZYŃSKA, Czynniki rozwoju i zagrożenia demokracji w dobie globalizacji, w: tamże, s. 224-235.

${ }^{27}$ Autorem rozróżnienia między trudną do zatrzymania globalizacją a możliwym do zmodyfikowania przez odpowiednie decyzje polityczne globalizmem jest Ulrich Beck. Podaję za: I. GABRIEL, Erosion der Demokratie?, s. 8.
} 
W konsekwencji globalizacji demokratyczne państwo traci swą monopolistyczną pozycję na scenie światowej. Osłabienie jego suwerenności wskutek dyfuzji władzy - przejęcia jej części albo przez instytucje ponadnarodowe, albo przez globalnych aktorów gospodarczych sprowokowało wystąpienia różnych populistycznych ruchów sprzeciwu ${ }^{28}$. W ostatnim ćwierćwieczu szczególnie silną pozycję w strukturze globalnego rządzenia uzyskały natomiast korporacje ponadnarodowe. Charakterystyczne dla globalizacji: deterytorializacja zjawisk gospodarczych, ich dematerializacja, delokalizacja produkcji i usług dodatkowo osłabia pozycję państwa narodowego wobec ponadnarodowych podmiotów gospodarczych. To nie państwo dyktuje warunki firmom, ale odwrotnie. Konkurując o pozyskanie inwestorów zagranicznych, jest zmuszone do ustępstw podatkowych i deregulacji rynku, co oczywiście ogranicza możliwości prowadzenia polityki gospodarczej i społecznej na miarę oczekiwań obywateli. Niewątpliwie „globalizacja podkopuje tradycyjną rolę państwa”. Jak zauważył Harold James, charakterystyczne dla okresu pierwszej rewolucji przemysłowej prawo rosnących wydatków państwowych (sformułowane jeszcze w XIX wieku przez Adolfa Wagnera) ,już uległo odwróceniu w przypadku kilku społeczeństw”. Niektóre kraje „drastycznie zmniejszyły udział wydatków publicznych w dochodzie narodowym" ${ }^{29}$. Prowadzi to do erozji demokratycznie legitymizowanej władzy państwa narodowego. Nierównowaga między koncernami działającymi w skali globalnej a parlamentami narodowymi ogranicza polityczną władzę decyzyjną i szkodzi przez to demokracji. Na ograniczenie państwowej suwerenności i związaną $\mathrm{z}$,nowym międzynarodowym kontekstem ekonomiczno-handlowym i finansowym" modyfikację politycznej władzy państw zwrócił też uwagę Benedykt XVI w encyklice Caritas in veritate (CIV 24).

Nieobojętna dla kondycji demokracji w warunkach globalizacji jest następnie marginalizacja pracy. W warunkach globalizacji dysproporcja między pracą i kapitałem - na niekorzyść pracy - ulega pogłębieniu ${ }^{30}$. Ze swej istoty praca jest bowiem - ze zrozumiałych względów - znacznie bardziej immobilna niż kapitał, zwłaszcza finansowy. Konsekwencją jest nie tylko bezrobocie, ale też niepełne zatrudnienie $\mathrm{i}$ w ogóle trudność zakorzenienia się na rynku pracy, zwłaszcza młodzieży. Pojawia się zjawisko „biednych pracujących” (working poor). Na globalnym rynku pracy obserwuje się ciągły ruch i przetasowania, pozostawiają-

${ }^{28}$ Por. F.-W. STEINMEIER, ,, Demokratie ist liberal - oder sie ist nicht”, ,Frankfurter Allgemeine Zeitung“ 27 września 2018 (nr 225).

${ }^{29}$ H. JAMES, Koniec globalizacji, s. 278-279.

30 Szerzej na temat związanych z globalizacją przemian w świecie pracy por. A. DYLus, Gospodarka w perspektywie etycznej i religijnej, Warszawa: Wydawnictwo Naukowe UKSW 2016, s. $42-56$. 
ce za sobą sporo ofiar. Stabilne w epoce przemysłowej stosunki pracy, regulowane trwałymi umowami o pracę, nad których realizacją czuwali partnerzy społeczni, bezpowrotnie należą do przeszłości. Gwałtownie następuje serwicyzacja gospodarki. Często ma miejsce zatrudnianie na mobilnych zasadach (,umowy śmieciowe"), bez gwarancji bezpieczeństwa socjalnego.

W ocenie niektórych ekspertów kompleks zagadnień związanych z marginalizacją pracy urasta nawet do „nowej kwestii społecznej”31, na którą składa się m.in. bolesne zjawisko prekariatu. Kojarzone są z nim najczęściej: brak bezpieczeństwa, niepewność, lęk, obawa o przyszłość. Konsekwencje tej sytuacji daleko wykraczają poza stosunki pracy. Według Guya Standinga psychologicznymi i społecznymi skutkami charakterystycznego dla prekariatu zachwiania bezpieczeństwa są: gniew, anomia, objawiająca się biernością wynikającą z niepowodzeń, niepokój, którego źródłem jest lęk o przyszłość i alienacja zrodzona z braku szacunku do własnej pracy. Wszystko to grozi utratą poczucia tożsamości związanej z pracą oraz wypchnięciem jednostki poza instytucje ładu rynkowego i porządku społecznego ${ }^{32}$. Jeszcze inną twarzą prekariatu jest społeczna izolacja jednostek w procesie pracy. Oczywiście, wszystkie te przemiany w świecie pracy mogą wywoływać wielorakie perturbacje osobiste i społeczne. Przede wszystkim spada poczucie bezpieczeństwa socjalnego i społecznego. W ten sposób tworzą się idealne warunki dla mobilizacji „potencjału antydemokratycznego”. Tym bardziej, że zasłużone w obronie uprawnień pracowniczych związki zawodowe i w ogóle demokracja gospodarcza również przeżywają głęboki kryzys.

Wyraża się on głównie ,spadkiem stopy uzwiązkowienia”. Naturalnym środowiskiem związków zawodowych są fabryki - wielkie zakłady przemysłowe. Trudniej odnajdują się natomiast w mobilnym sektorze małych i średnich przedsiębiorstw, działających na mocno konkurencyjnych rynkach oraz zatrudniających pracowników na nietypowych zasadach i w elastycznym czasie pracy. Oznacza to, że związków zawodowych nie ma „tam, gdzie są najpotrzebniejsze" ${ }^{\prime 3}$.

Gospodarka światowa jest w znacznym stopniu zdematerializowana. Ogromnie wzrosło znaczenie kapitału finansowego. Nastąpił dynamiczny, niekontrolowany rozwój transakcji finansowych. Te zaś w dużej mierze mają charakter spekulacyjny. Słusznie zatem system oparty na takim hazardzie określa się

${ }^{31}$ Por. M. RymsZA, Nowa kwestia społeczna?, „Więź” 2015/3(661), s. 15.

32 Por. G. Standing, Prekariat. Nowa niebezpieczna klasa, Warszawa: PWN 2014, s. 65-73; cyt. za: M. BEDNARSKI, Czas pracy w polskiej gospodarce. Ewolucja, jej przyczyny i konsekwencje zmian, w: Ekonomia jest piękna? Ksiegga dedykowana Profesorowi Jerzemu Wilkinowi, red. Ł. Hardt, D. Milczarek-Andrzejewska, Warszawa: Wydawnictwo Naukowe Scholar 2015, s. 147.

${ }^{33}$ M. BEDNARSKI, Czas pracy w polskiej gospodarce, s. 144. 
„kapitalizmem kasyna”. Niekiedy w ogóle odmawia się mu miana „kapitalizmu”. Każda wolność, także wolność rynkowa potrzebuje reguł - przypomniał w jednym ze swoich ostatnich wywiadów Ralf Dahrendorf ${ }^{34}$. Podobne treści znajdujemy w Centesimus annus. Wyraźnie czytamy tam, że działalność gospodarcza „nie może przebiegać w próżni instytucjonalnej, prawnej i politycznej” (CA 48). Nie do przyjęcia jest ,system, w którym wolność gospodarcza nie jest ujęta w ramy systemu prawnego, wprzęgającego ją w służbę integralnej wolności ludzkiej" (CA 42).

Tymczasem wbrew tym zdecydowanym przestrogom, w ostatnim czasie kapitalizm finansowy usamodzielnił się. Takie operacje, jak np. spekulacje na długach, są przykładem działań niczym nie uregulowanych. Zdaniem Dahrendorfa taki pozbawiony reguł obszar trudno w ogóle nazwać rynkiem ${ }^{35}$. Ekspansja zderegulowanych „rynków” finansowych powoduje zaś, że gospodarka staje się bardzo podatna na nieoczekiwane wstrząsy. Wielki kryzys finansowy i gospodarczy, który w 2008 r. wybuchł w USA i szybko ogarnął cały świat, pokazał kruchość „sfinansjalizowanej” gospodarki. Formą ucieczki przed generowanymi przez kryzys konfliktami społecznymi jest zapożyczanie się u przyszłych pokoleń. Oznacza to ogromne zadłużenie wielu państw, wręcz zagrażające ich suwerenności. Nic dziwnego, że kryzys finansowy i gospodarczy pierwszej dekady XXI wieku prowokował pytania, czy nie zagraża on demokracji. Owszem, demokrację erodują głównie czynniki endogenne, w tym degradacja mechanizmów odpowiedzialności rządzących. Jednak gwałtowny spadek wzrostu gospodarczego też może jej zagrażać ${ }^{36}$.

Spośród różnych konsekwencji globalizacji i kryzysu gospodarczego bodaj najgroźniejszy dla demokracji jest wzrost nierówności społecznych. Na sporządzonej przez Samuela Huntingtona liście 25 zmiennych branych pod uwagę przy wyjaśnianiu procesu demokracji i demokratyzacji „relatywnie równy podział dochodu i/lub bogactwa narodowego" znalazł się na drugim miejscu (po „wysokim poziomie ogólnego dobrobytu”, a przed ,gospodarką rynkową”) ${ }^{37}$. Powodowane globalizacją rozwieranie się nożyc nierówności szkodzi demokracji, gdyż powoduje zachwianie bezpieczeństwa socjalnego. Dochodzi do zetknięcia się antyegalitarnego wolnego rynku z egalitarną demokracją. Po przekroczeniu pewnego progu nierówności ekonomicznych i socjalnych (jego wyso-

${ }^{34}$ Por. R. DAHRENDORF, Keiner fragt, was mit den Managermillionen geschieht, rozm. P. Bahners, A. Cammann, „Frankfurter Allgemeine Zeitung” 10 października 2008.

${ }^{35}$ Por. tamże.

${ }^{36}$ Por. B. Nowotarski, [wypowiedź nt.] Demokracja i kryzys, „Zarządzanie Publiczne” 2011, nr 16-17(2-3), s. 104.

${ }^{37}$ Por. S. Huntington, Trzecia fala demokratyzacji, s. 57. 
kość będzie inna w różnych społecznościach i kulturach), demokracja może zostać zawieszona. Podstawowe demokratyczne wolności stają się wówczas bezbronne wobec ruchów populistycznych, odwołujących się do frustracji, fobii, agresji. Zbyt ostentacyjna konsumpcja z jednej strony i pauperyzacja $\mathrm{z}$ drugiej, mogą prowadzić do groźnego konfliktu. Stanowią pożywkę dla demagogicznych stronnictw politycznych i ich ludowych trybunów. W ten sposób bezpośrednio zagrażają demokratycznemu porządkowi społecznemu ${ }^{38}$. Z drugiej zaś strony również konsumizm nie sprzyja demokracji. Jak czytamy w Centesimus annus, zdominowanie życia kategoriami „mieć i używać” powoduje, że człowiek „nie może być wolny" (CA 41).

Tymczasem w ciągu ostatnich kilku dekad nierówności dochodowe i majątkowe, tak w skali międzynarodowej, jak i wewnątrz poszczególnych społeczeństw, ogromnie wzrosły - i to nie tylko w USA. W Europie wzrost dysproporcji związany był $\mathrm{z}$ demontażem państwa dobrobytu, z ograniczonymi finansowymi możliwościami prowadzenia przez państwo redystrybucyjnej polityki społecznej i z redukcją dostarczanych obywatelom dóbr publicznych, co wywołało (chociażby w Grecji) falę sprzeciwu i kontestacji wobec liberalnej demokracji. Przy zdecydowanie krytycznym podejściu Jana Pawła II do welfare state, był on jednak przekonany, że właśnie na państwie (i całym społeczeństwie) „spoczywa obowiązek obrony dóbr zbiorowych" (CA 40). Niedopełnienie tego obowiązku powoduje utratę przez obywateli wiary, że demokratyczne rządy są w stanie uporać się z trudnościami.

Sygnalizowane tu uciążliwe skutki gospodarczej globalizacji, wywołujące głębokie niezadowolenie społeczne doprowadziły w ostatnich kilku latach do licznych protestów, a nawet do ukonstytuowania się ruchów anty- i alterglobalistycznych. Brak zaufania do automatyzmu wolnorynkowego wymusił podjęcie przez rządy pewnych działań hamujących globalizacyjną dynamikę. Czy jednak odwrócenie procesów globalizacji jest w ogóle możliwe?

\section{PROBLEM MOŻLIWOŚCI DEGLOBALIZACJI}

Podejmując temat deglobalizacji zakładamy, że da się spowolnić (jeśli nie zatrzymać) lub „ująć w cugle” procesy globalizacji, że można ograniczyć ich dynamikę. Wobec deterministycznych ujęć globalizacji jeszcze niedawno wydawało się to niemożliwe. Zamysły odwrócenia globalizacyjnych trendów kwalifi-

38 Por. A. DYLus, Polityka $w$ perspektywie etycznej i religijnej, Warszawa: Wydawnictwo UKSW 2016, s. 343-344. 
kowano jako utopijne. Metafory dżinu wylanego z butelki, którego nie da się umieścić tam z powrotem, czy ludzkości pędzącej na grzbiecie tygrysa (B. Barber) utrwalały przekonanie, że dla globalizacji nie ma alternatywy. Słynny slogan Pierre'a Bourdieu TINA - There is no alternative, spopularyzowany przez Margaret Thatcher dla uzasadnienia prowadzonej przez nią neoliberalnej polityki gospodarczej, odnoszono właśnie do globalizacji. Inne ujęcia, np. obecne w nauczaniu społecznym Kościoła stanowisko, że „globalizacja nie następuje na zasadzie prawa naturalnego" ${ }^{39}$, z trudem przebijały się do opinii publicznej.

Historia gospodarcza ostatnich kilku stuleci uczy jednak ostrożności w odniesieniu do poglądu o rzekomej nieodwracalności procesu globalizacji. Prawdopodobnie mylił się Benjamin Barber twierdząc, że „kapitalizmu nie da się zdeglobalizować" ${ }^{40}$. Owszem, trudno sobie wyobrazić powrót do stanu sprzed drugiej rewolucji przemysłowej, zwłaszcza rewolucji informatycznej, która przyspieszyła globalizacyjną dynamikę. Niemniej pokusa, o której wspomina Harold James, „by postrzegać gospodarkę światową jako rodzaj gigantycznego wahadła, poruszającego się od fazy liberalizacji do fazy jej odrzucenia i ponownego narzucenia kontroli", wcale nie wydaje się oderwana od rzeczywistości. Podobnie idee towarzyszące rozwojowi gospodarczemu „poruszają się po wielkim wahadle" ${ }^{41}$.

Rzeczywiście, praktyka i teoria fizjokratyzmu z jego hasłem laissez faire ustąpiła miejsca interwencjonistycznemu merkantylizmowi, wdrażanemu przez państwa kierujące się oświeconym absolutyzmem. Z kolei nawiązujący do fizjokratyzmu klasyczny liberalizm towarzyszył XIX-wiecznej globalizacji. W okresie międzywojnia została ona jednak zatrzymana. Po I wojnie światowej wahadło wychyliło się bowiem ku nacjonalizmowi i zamykaniu się w obrębie gospodarek narodowych. Interwencjonistyczny keynesizm, będący odpowiedzią na wielki kryzys gospodarczy lat 30 . XX wieku, ze swą ideą welfare state stanowił doktrynalne zaplecze rozwoju wielu państw po II wojnie światowej. Po nim - od lat 70. $\mathrm{XX}$ wieku - znów nastąpił zwrot ku liberalizmowi. Właśnie neoliberalne teorie stanowiły zaplecze uruchomienia (się) kolejnej fazy gospodarczej globalizacji. W drugiej dekadzie XXI wieku wahadło rozwoju po raz kolejny wychyla się $\mathrm{w}$ drugą stronę, a tony antywolnorynkowe, towarzyszące np. kampanii prezydenckiej w USA w 2016 r., były słyszalne i na wiecach kandydatów republikań-

${ }^{39}$ O przyszłość w solidarności i sprawiedliwości, Wspólne Słowo Rady Kościoła Ewangelickiego w Niemczech i Konferencji Episkopatu Niemiec, nr 88 („Społeczeństwo” 1997, nr 3, s. 427).

40 B. R. BARBER, Globalny dzin, ,Gazeta Wyborcza” 1-2 lipca 2000.

${ }^{41}$ H. JAMES, Koniec globalizacji, s. 271; 282. 
skich, i demokratycznych. Zdumiewająca była chociażby neomerkantylistyczna retoryka Hillary Clinton ${ }^{42}$.

Jeśli historia rzeczywiście jest magistra vitae, to falsyfikuje ona tezę o niemożliwości deglobalizacji. Wbrew Barberowi uczy, że kapitalizm da się zdeglobalizować. Jakie dziś są tego symptomy?

\section{SYMPTOMY DEGLOBALIZACJI W XXI WIEKU}

Reakcją na procesy globalizacji uzasadnianą troską o zachowanie suwerenności gospodarki narodowej jest „powrót państwa”, tj. odradzanie się tendencji autarkicznych w polityce gospodarczej. Potwierdzałoby to sformułowany już w 1997 r. przez ekonomistę Dany'ego Rodrika szeroko obecnie dyskutowany trylemat, zgodnie z którym spośród trzech wartości: narodowej suwerenności, demokracji politycznej i pełnej integracji z globalnym wolnym rynkiem tylko dwie mogą być udziałem nowoczesnych państw ${ }^{43}$. Otóż dziś w wielu państwach wysoką koniunkturę notuje opcja wzmacniania właśnie narodowej suwerenności, kosztem gospodarczej globalizacji (o losach demokracji - za chwilę). W każdym razie ,globalizacja stała się ulubionym celem ataków dla ludzi, którzy apelują o silniejszą rolę państwa w gospodarce" ${ }^{44}$.

Choć pokusy renacjonalizacji gospodarek cały czas towarzyszyły globalizacji, nasilają się one w okresach kryzysu. Ekonomiczne załamanie, tak w latach 30. XX wieku, jak i po 2008 r., prowadzi do odwrotu niewidzialnej ręki rynku na rzecz widzialnej ręki państwa. Przeświadczeniem (często słusznym), iż odpowiedzialne za destabilizację są międzynarodowe przepływy finansowe, uzasadnia się powrót do regulacji i kontroli. W każdym razie „,dla przeciwników swobody migracji, przepływu towarów i transakcji kapitałowych wielki kryzys stanowił okazję do cofnięcia wskazówek zegara. Silne państwo narodowe oraz swobodny przepływ kapitału znalazły się na przeciwległych biegunach" 45 .

Inną, bardziej anarchizującą odpowiedzią na kryzys były ruchy antysystemowe, protestujące przeciw „wszechmocy rynku”. Były to ruchy o różnej proweniencji ideowej: od „Oburzonych”, „Occupy” czy alterglobalistycznego ATTAC-u po Anty-ACTA. Ich cechą wspólną było romantyczne marzenie

\footnotetext{
42 Por. W. von Peterddorff, Ph. Plickert, Die neue alte Angst vor der Globalisierung, „Frankfurter Allgemeine Zeitung“ 20 sierpnia 2016 (nr 194).

${ }^{43}$ Por. J. Hausner, [wypowiedź nt.] Demokracja i kryzys, „Zarządzanie Publiczne” 2011, nr 16-17(2-3), s. 112; M. Kuź, Globaliści vs. Lokaliści, „Internetowy Miesięcznik Idei” 3 (57)2015.

${ }^{44}$ H. JAMES, Koniec globalizacji, s. 273.

${ }^{45}$ Tamże, s. 268. Ta konstatacja odniesiona do okresu międzywojennego jest i dziś zadziwiająco aktualna.
} 
o świecie bez rynku i alienującego kapitału, w którym kapitalizm raz na zawsze zostanie pogrzebany.

Prowadzeniu polityki mającej na celu dowartościowanie gospodarki narodowej sprzyja odwoływanie się do patriotyzmu gospodarczego ${ }^{46}$. Pojęcie to znów stało się modne, chociażby w USA czy Francji. W Polsce w kręgach politycznych zainteresowanie patriotyzmem gospodarczym wyraźnie wzrosło po 2015 r., a premier Beata Szydło w listopadzie 2017 r. mówiła nawet o „zasadzie patriotyzmu gospodarczego", którą kieruje się rząd. Do patriotyzmu odwoływał się też Mateusz Morawiecki, prezentujący w lutym 2016 r. - jako wicepremier - swój plan. W ramach zadeklarowanej reindustrializacji zapowiedziano mocne wsparcie prywatnych polskich firm i budowanie marek ,polskiej Nokii”, m.in. dronów, elementów samolotów (projekt „Żwirko i Wigura”), promów pasażerskich, polskich ekologicznych pojazdów dla komunikacji miejskiej i regionalnej (projekt „Luxtorpeda 2.0”), polskich maszyn budowlanych. Państwo ma też wspierać rozwój innowacyjnych firm i ich ekspansję zagraniczną ${ }^{47}$. Podobne wątki, deklarujące „romantyzm celów, pozytywizm środków” pojawiły się w exposé premiera Morawieckiego 12 grudnia 2017 r. W nawiązaniu do dewizy Stanisława Wyspiańskiego „Polska to wielka rzecz”, zapowiedziano wielką modernizację Polski, w tym m.in. wzmocnienie polskich firm.

Warto zaznaczyć, że deglobalizacja nie polega dziś na doskonałej separacji wszystkich rynków wewnętrznych od rynków światowych. Wiąże się jednak z pewnym zamykaniem gospodarek i ochroną własnych rynków. Trudno niekiedy kwestionować racjonalność takiej polityki gospodarczej. Może ona być odpowiedzią na imperialne ambicje niektórych państw, np. Rosji i na wzrost napięcia międzynarodowego. Wyrazem troski o własne bezpieczeństwo będzie wtedy rozbudowa przemysłu zbrojeniowego, subwencje dla przemysłu ciężkiego czy długa lista tzw. sektorów strategicznych, które mają podlegać kontroli państwowej. W naszym regionie Europy przedmiotem troski wielu państw, w tym Polski, jest bezpieczeństwo energetyczne - wobec zagrożeń generowanych wskutek monopolizacji przez Gazprom dostaw gazu. Budowa drugiej nitki gazociągu NordStream wzmogła te obawy. Tyle tylko, że nawiązujące do fikcji suwerenności „w starym stylu” ambicje samodzielnego przezwyciężania przez państwa europejskie różnych wielkich wyzwań, w XXI wieku są już anachroniczne. Wy-

\footnotetext{
${ }^{46}$ Szerzej nt. patriotyzmu gospodarczego por. np. A. DYLus, Patriotyzm gospodarczy. Wielowymiarowość i ambiwalencja, „Społeczeństwo” 2018, nr 1, s. 29-55; K. KIETLIŃsKI, Wspótczesne wyzwania patriotyzmu gospodarczego, „Społeczeństwo” 2018, nr 2, s. 39-51.

47 Omówienie ,planu Morawieckiego” por. P. LEGUTKO, Rząd ucieka do przodu, „Gość Niedzielny" 28 lutego 2016.
} 
daje się, że bardziej realną szansą na dokonanie tego jest połączenie sił - zintegrowane działanie państw w ramach Unii Europejskiej ${ }^{48}$.

Bodaj najbardziej widocznym symptomem deglobalizacji jest protekcjonizm ${ }^{49}$. Obok promocji eksportu jest to standardowe narzędzie polityki gospodarczej, mającej na względzie ochronę produkcji i handlu krajowego przed konkurencją zagranicy. Obciążając importowane towary wysokimi cłami przywozowymi, wspiera się przecież rodzimych producentów i buduje w ten sposób potęgę własnego kraju. Taki zamysł ochrony rodzimego hutnictwa przyświecał decyzji z 2018 r. obłożenia cłami importowanych do USA towarów ze stali i aluminium. Narzędziem polityki protekcjonistycznej bywają też kontyngenty importowe, ograniczające wielkość importu oraz różne utrudnienia administracyjne (np. szczegółowe kontrole celne, wysokie wymogi fitosanitarne dla artykułów rolnych) powstrzymujące import.

Ambiwalencja polityki protekcjonizmu polega na tym, że choć przejściowo można dzięki niej rzeczywiście osiągać pewne korzyści, na dłuższą metę zwykle powoduje działania odwetowe ze strony dotkniętych nią państw. Prowadzi do zahamowania wymiany międzynarodowej, a w skrajnych wypadkach do wojen handlowych. Należy oczekiwać, że zapowiedziane przez Donalda Trumpa obłożenie ok. 6 tysięcy asortymentów towarów importowanych z Chin do USA 10-procentowymi cłami spotka się z retorsją ze strony ChRL. Wojny handlowe mają przy tym dziś często charakter multilateralny. Napięte ostatnio (2018 r.) stosunki handlowe między USA a Unią Europejską grożą wybuchem takiej właśnie wojny.

Jedna $\mathrm{z}$ form protekcjonistycznego odwrotu od wolnego rynku, rozpowszechniona głównie wśród państw rozwiniętych, ukryta bywa za zasłoną rzekomej obrony przed dumpingiem socjalnym czy ekologicznym. Polityka handlowa bogatych krajów zakłada mianowicie, że wymiana ma być prowadzona według zasad ,uczciwego handlu”. Ten zbożny postulat, dopuszczający do wymiany - pod groźbą zastosowania ceł antydumpingowych - jedynie towary wyprodukowane według wysokich standardów socjalnych i ekologicznych, oznacza de facto zablokowanie importu $\mathrm{z}$ biedniejszych krajów, które nie są $\mathrm{w}$ stanie spełnić tych kosztownych kryteriów. Również Unię Europejską oskarża się o prowadzenie otwartej lub zakamuflowanej polityki protekcjonistycznej. Trudny do jednoznacznej oceny $\mathrm{w}$ tym względzie jest spór wewnątrz Unii w sprawie „pracowników delegowanych”, m.in. firm transportowych. Francja i Niemcy

${ }^{48}$ Por. N. LAMmERT, Visionen in der Politik, rozm. B. Löhmann, „Die Politische Meinung” 2017, nr 547, s. 27.

${ }^{49}$ Szerzej na ten temat por. A. DyLus, Patriotyzm gospodarczy, s. 43-45. 
domagały się zrównania warunków zatrudnienia pracowników tych firm, zaś Polska i inne państwa naszego regionu oraz Hiszpania i Portugalia sprzeciwiały się takiemu rozwiązaniu. $\mathrm{Z}$ jednej strony wysuwane były oskarżenia o protekcjonizm, zaś z drugiej - oskarżenia o dumping socjalny.

Zazwyczaj jednak sytuacja jest mniej kontrowersyjna, uzasadniająca rozgoryczenie słabszych kontrahentów: „Kraje rozwijające się uważają warunki stawiane przez Zachód za hipokryzję, ukrywanie nowego protekcjonizmu pod maską humanistycznej troski o sprawiedliwość międzynarodową"50. Groźbę wykorzystania protekcjonizmu przez najbogatszych dla utrwalenia nierówności rozwojowych sygnalizuje się też w nauczaniu społecznym Kościoła. Wyraża się sprzeciw wobec takiego ,zniekształcania systemu handlu międzynarodowego, który często z powodu protekcyjnej polityki wyklucza produkty pochodzące z krajów biednych oraz przeszkadza w rozwoju działalności przemysłowej"51. Jan Paweł II w encyklice Sollicitudo rei socialis (SRS) z dezaprobatą pisał o „dyskryminacji wyrobów początkujących przemysłów w krajach na drodze rozwoju”. W związku z tym postulował ,reformę międzynarodowego systemu handlowego obciążonego protekcjonizmem" (SRS 43).

Niemniej istnieją też racje przemawiające za protekcjonistycznym korygowaniem wolnej wymiany międzynarodowej. Cła są potrzebne krajom słabszym, aby umożliwić wykorzystanie ich potencjału gospodarczego. Przejściowo - aż do osiągnięcia pełnej zdolności konkurencyjnej - wspierają one nowe gałęzie produkcji, chronią na przykład krajowy przemysł przed konkurencją tanich zagranicznych towarów. W każdym razie wydaje się, że w pewnych warunkach protekcjonizm - choć łamie zasady wolnego handlu - rzeczywiście może być usprawiedliwiony.

Nie można tego powiedzieć o innym symptomie deglobalizacji, jakim jest izolacja państw rozwijających się od bogatych „wyzyskiwaczy”. W ten sposób ma nastąpić wyrwanie się z zaklętego kręgu niedorozwoju i ubóstwa. Państwa te odwołują się przy tym do tzw. teorii uzależnienia, zgodnie z którą na wolnej wymianie bogacą się jedynie kraje rozwinięte. Biedni kontrahenci są rzekomo wyzyskiwani i coraz bardziej uzależnieni od bogatych. Wnioski z takiej identyfikacji przyczyn gospodarczego niedorozwoju są dla nich oczywiste: jedyną drogą przezwyciężenia zapóźnienia, a tym samym odzyskania gospodarczej suwerenności jest izolacja od rynków światowych ${ }^{52}$. Na kontrproduktywność takiego

\footnotetext{
${ }^{50}$ H. JAMES, Koniec globalizacji, s. 296.

${ }^{51}$ PaPIESKa Rada IUstitia ET PaX, Kompendium nauki społecznej Kościoła, Kielce: Jedność 2005, nr 364 (s. 239).

52 Szerzej na ten temat por. A. DyLus, Globalny rynek $i$ jego granice, Warszawa: Centrum im. Adama Smitha \& Instytut Politologii UKSW 2001, s. 54-69.
} 
myślenia i działania zwraca się uwagę w nauczaniu społecznym Kościoła. W Centesimus annus czytamy: „Doświadczenia ostatnich lat wykazały, że Kraje, które wybrały izolację, zatrzymały się lub cofnęły w rozwoju, natomiast posunęły się naprzód te, które umiały się włączyć w ogólny system wzajemnych powiązań gospodarczych na poziomie międzynarodowym" (CA 33).

Bodaj najbardziej gwałtowne symptomy deglobalizacji są reakcją na chaotyczną ,globalizację kulturową”, prowadzącą do zachwiania tożsamości wspólnot lokalnych, regionalnych czy narodowych. Związana z globalizacją intensyfikacja relacji interkulturowych przyczynia się do powstawania „globalnej wioski”, ale nie do ukształtowania globalnej kultury. Przesłanką rozwoju kulturowego jest zawsze podejmowanie egzystencjalnych pytań o sens. Tymczasem „globalna wioska" przyjmuje raczej cechy McWorld. Określa ją po prostu konsumpcja tych samych dóbr i usług. Taka prymitywna standaryzacja kultury oznacza jej śmierć. Oczywistą reakcją obronną będzie wówczas kulturowa fragmentaryzacja. Ożywienie ducha plemiennego, odradzanie się partykularyzmów i fundamentalizmów są zrozumiałe właśnie w kontekście zagrożenia tożsamości kulturowej ${ }^{53}$. Słynną teorię Samuela Huntingtona o zderzeniu kultur i ścieraniu się cywilizacji można potraktować m.in. jako interpretację kulturowej deglobalizacji.

W nauczaniu społecznym Kościoła poszanowanie wartości ludzkich kultur uznaje się - obok niezbywalnej godności osoby ludzkiej - za jedną z dwóch zasad umożliwiających etyczne rozeznanie w warunkach globalizacji. Mocnymi słowami określono ewentualne odstępstwo od tej zasady Poniżanie lub niszczenie różnorodności kulturowej byłoby „nową wersją kolonializmu” ${ }^{4}$. W związku z tym - jak czytamy w adhortacji Ecclesia in America (EA) z 1999 r. - pożądana jest wielka czujność wobec tzw. globalizacji kulturalnej, dokonującej się głównie za sprawą mass mediów. Praktycznie ,wszędzie narzucają one nowe skale wartości, często arbitralne i w istocie materialistyczne, wobec których trudno jest utrzymać przywiązanie do wartości ewangelicznych" (EA 20). Niesie to ze sobą groźbę ,utraty wartości przez kultury lokalne na rzecz źle rozumianego ujednolicenia" (EA 55).

Jeszcze innym symptomem deglobalizacji jest populizm. Niewątpliwie jest to zjawisko ambiwalentne, a określające je pojęcie - bardzo wieloznaczne. Współczesny tzw. nowy populizm, jako podstawowe wyposażenie skutecznych polityków, odwołuje się do gniewu ludu mającego swe źródło m.in. w zawodności globalizacji. Amerykańskim robotnikom i klasie średniej obiecywano awans

\footnotetext{
${ }^{53}$ Por. tamże, s. 46-47.

${ }^{54}$ Jan PaWeŁ II, Globalizacja będzie tym, co uczynia z niej ludzie, Przemówienie z 27 kwietnia 2001 r. do uczestników sesji plenarnej Papieskiej Akademii Nauk Społecznych, nr 4 (tytuł pochodzi od redakcji „Więzi”), „Więź” 2001, nr 10(516), s. 50.
} 
społeczny. Tymczasem grupy te nie tylko utraciły miejsca pracy, ale także odarto je z marzeń o awansie. Według obliczeń badacza rynku pracy Davida, Autora z Massachusetts Institute of Technology, import tanich towarów z Chin do USA spowodował $\mathrm{w}$ latach 1999-2011 utratę 1,5 mln miejsc pracy. Poważne straty miejsc pracy, zwłaszcza w grupie pracowników słabo wykwalifikowanych, odnotowano w Wielkiej Brytanii, Francji, Hiszpanii czy Norwegii. Jeśli dodać do tego gwałtowne nasilenie migracji, a wręcz kryzys uchodźczy, niepokojącą obecność islamu w Europie czy zamachy terrorystyczne, trudno się dziwić nastrojom niepewności i niepokoju. Jak zauważył Jeffrey Sachs, wyborcy Donalda Trumpa i zwolennicy Brexitu nie bez racji uważają, że ,imigrację pozostawiono poza kontrolą, że destabilizuje ona kulturowo i szkodzi ich interesom gospodarczym" ${ }^{\text {"55 }}$. Wobec obojętności i braku zainteresowania elit tą sytuacją ${ }^{56}$ nie dziwi fakt, że wybory prezydenckie w USA wygrał człowiek obiecujący wydalenie z kraju nielegalnych imigrantów, zwłaszcza Meksykanów, oraz politykę protekcjonistyczną, we Francji umacnia się Front Narodowy Marine Le Pen, a w Europie Środkowo-Wschodniej ton nadają politycy mocno akcentujący wagę narodowej suwerenności.

Odmienne od powszechnie przyjętego spojrzenie na populizm proponuje Chantal Delson. Już tytuł jej publikacji: „Populizm” jako protest wobec nadmiernego uniwersalizmu i obrona zakorzenienia daje do myślenia. Odróżniając demagogię polityka, schlebiającego pragnieniom i zachciankom ludu od jego populizmu, tj. „braniu pod uwagę woli ludu, która przeciwstawia się jednomyślnemu, uniwersalnemu oświeceniu" 57 , sympatyzuje z tym ostatnim. Doceniając wagę partykularnego zakorzenienia, broni obrońców własnej tożsamości i odrębności. Co więcej, uważa, że „to populiści najlepiej odzwierciedlają klasyczny ideał obywatela". Oni domagają się dziś obniżenia długu narodowego, kontroli zbyt wysokich zasiłków, nadzorowania imigracji, wzrostu solidarności, zachowania rodziny i grup przynależności. Są nawet gotowi „umrzeć za ojczyznę”. Wbrew globalistycznym kosmopolitom, dobro ojczyzny stawiają nad dobrem globalnym. Jeśli przyjąć, że populistom zależy na dobru wspólnym, że rzeczywiście chcą „bronić całości zakrojonych szerzej niż jednostka, lecz jeszcze cząstkowych" ${ }^{58}$, to takie oblicze deglobalizacji zasługuje na szacunek.

55 Podaję za: W. von Petersdorff, PH. Plickert, Die neue alte Angst.

56 Tytułowe sformułowanie książki Bunt mas czy kryzys elit? (red. A. Dylus, S. Sowiński, Wrocław: Wydawnictwo TUM Wrocławskiej Księgarni Archidiecezjalnej 2018) sugerujące alternatywę w identyfikacji podmiotów odpowiedzialnych za opisywaną tu sytuację, należałoby raczej interpretować jako koniunkcję.

${ }^{57}$ CH. Delsol, ,Populizm” jako protest wobec nadmiernego uniwersalizmu i obrona zakorzenienia, „Chrześcijaństwo - Świat - Polityka” 2017, nr 21, s. 98.

${ }^{58}$ Tamże, s. 102-103. 
Warto jednak - za Ch. Delsol - postawić pytanie, ,czy populizm jest antydemokratyczny?" I szerzej, jaka jest kondycja demokracji w warunkach deglobalizacji? Czy silne państwo, którego powrotu domagają się dziś obywatele, będzie jeszcze państwem demokracji liberalnej?

\section{KONDYCJA DEMOKRACJI \\ W WARUNKACH DEGLOBALIZACJI}

Odpowiedź na pierwsze z tych pytań, udzielana - zdaniem Delsol - przez samych populistów brzmi podobnie, jak niegdyś uczestników Praskiej Wiosny w odniesieniu do socjalizmu: demokracja - tak, wypaczenia - nie. Populizm bynajmniej nie zwalcza demokracji; przeciwnie, broni jej istoty. Zwalcza bowiem to, co ją koroduje: ukryte porozumienia, nieprzejrzystość, ideologiczny monopol, „zabetonowanie” sceny politycznej, a więc brak faktycznej wolności wyboru. Partie populistyczne nie chcą niszczyć demokracji, ale pragną zostać włączone w jej przestrzeń. Nie planują zniesienia instytucji przedstawicielskich, ale chcą takiej ich reformy, która pozwalałaby im zaistnieć ${ }^{59}$. Bardzo niebezpieczną cechą zazwyczaj ubogiego teoretycznie populizmu jest natomiast dowartościowanie charyzmy. Jak zauważa Delsol, ,przywódca jest ich żywą teorią. [...] Zepchnięcie tych nurtów na margines [...] wzmacnia ich sekciarski charakter, a miłosna relacja lidera i jego oddziałów nasila się wraz ze wzrostem oburzenia zewnętrznego: przywódca bezustannie obrzucany obelgami tym bardziej wyzwala u swoich zwolenników pragnienie obwołania go władcą"60.

Generalnie od demokracji nie odcinają się też, przynajmniej deklaratywnie, ruchy alterglobalistyczne. Choć czerpią one z bardzo różnych filozofii politycznych i niekiedy wzajemnie sprzecznych systemów ideologicznych, łączy je m.in. idea ,ponownego odkrycia demokracji”. Uczestnicy założonego w 2001 r. w Porto Alegre (Brazylia) Światowego Forum Społecznego są jednak przekonani, że „współczesny świat wymaga reinterpretacji pojęcia demokracji, przede wszystkim dlatego, że dominujący model demokracji przedstawicielskiej sprzyja skostnieniu elit władzy. Świat tymczasem potrzebuje demokracji oddolnej, obywatelskiej $[. .$.$] podporządkowania wszystkich relacji społecznych i ekonomicz-$ nych radykalnemu, partycypacyjnemu $i$ żywemu procesowi demokratycznemu". Te ogólne postulaty zostały uzupełnione kilkoma dodatkowymi, jak np. „wdrożenie demokratycznej kontroli nad zewnętrznym zadłużeniem, zainicjowanie

\footnotetext{
${ }^{59}$ Por. tamże, s. 101.

60 Tamże, s. 102.
} 
demokratycznej regulacji działania międzynarodowych korporacji, zapewnienie globalizacji negocjacji zbiorowych [...] monitorowanie kapitału oraz rządów przez instytucje społeczeństwa obywatelskiego" ${ }^{" 61}$. Tęsknoty różnych ruchów populistycznych i alterglobalistycznych za „prawdziwą” demokracją niewątpliwie są cennym kapitałem społecznym. Bez teoretycznego ugruntowania, bez stworzenia przekonujących ram intelektualnych i spójnych projektów politycznych wdrażania reform, trudno jednak oczekiwać realnej naprawy liberalnej demokracji.

Póki co wraz z załamaniem się globalizacji i „,powrotem państwa” sygnalizuje się raczej „odpływ demokracji”. Jak twierdzi Colin Crouch, od dawna żyjemy już w epoce ,postdemokracji”. Świadczą o tym chociażby: nowa fascynacja autorytaryzmem, kwestionowanie liberalnych osiągnięć, resentymenty kierowane przeciw partiom i politykom ${ }^{62}$. Już przed ćwierćwieczem przewidział to Samuel Huntington. Badane przez niego dotychczasowe meandry kolejnych przypływów i odpływów demokracji skłoniły go do sformułowania tezy, że jej przebieg następuje według reguły „dwa kroki do przodu, jeden do tyłu”63. Ogarnięci euforią towarzyszącą upadkowi reżimów komunistycznych po 1989 r., nie rejestrowaliśmy jego prognozy z 1991 r., że niebawem czeka nas „krok do tyłu”.

Tymczasem po dwudziestu latach badania dotyczące stanu demokracji w świecie, a ogłoszone przez „The Economist” potwierdziły te przewidywania ${ }^{64}$. Okazało się, że nawet w Europie, w krajach uznawanych za zaawansowane demokracje, stan tego ustroju uległ pogorszeniu (z wyjątkiem Europy Północnej). W badaniach uwzględniono przy tym m.in. poziom zaufania do instytucji - przede wszystkim do partii i polityków, stopień aprobaty samej idei demokracji, obniżenie się frekwencji wyborczej. Światłem ostrzegawczym dla demokracji są też sukcesy radykalnej prawicy w wielu państwach europejskich. Niepokojącymi symptomami uzasadniającymi stawianie pytania o przyszłość demokracji są dalej: spadek liczby członków tradycyjnych partii „ludowych” oraz niezwykle emocjonalne wystąpienia różnych ruchów protestu po prawej i lewej stronie politycznego spektrum ${ }^{65}$.

61 Postulaty Światowego Forum Społecznego omawia Piotr KOPIEC (Chrześcijańska wizja alterglobalizacji. Wkład Światowej Rady Kościołów, „Annales. Etyka w życiu gospodarczym” 20(2017), nr 3, s. 72-73). Do niektórych z nich nawiązuje Światowa Rada Kościołów.

${ }^{62}$ Taką też diagnozę postawił w 2018 r. prezydent Niemiec Frank-Walter Steinmeier na kongresie politologów we Frankfurcie. Por. „Demokratie ist liberal [...]”.

${ }^{63}$ S. Huntington, Trzecia fala demokratyzacji, s. 50.

${ }^{64}$ Por. A. Antoszewski, [wypowiedź nt.] Demokracja i kryzys, „Zarządzanie Publiczne” 2011, nr 16-17(2-3), s. 102.

${ }^{65}$ Por. W. Bergsdorf, Über die Zukunft der Demokratie, Köln: J.P. Bachem Medien 2017 (,Kirche und Gesellschaft“ Nr. 437), s. 3-4. 
Wobec opisanych wyżej niepokojących konsekwencji globalizacji oraz symptomów deglobalizacji, wśród obywateli państw świata zachodniego szerzy się wrażenie narastającego chaosu. Jak zauważył Udo Di Fabio, „Przez zachodnie demokracje przebiega nowe rozdarcie, wieje porywisty wiatr populizmu, następuje rebelia przeciw zimnym warunkom zglobalizowanej gospodarki oraz twardej logice ponadpaństwowego rządzenia" ${ }^{\text {66 }}$. W tej atmosferze rodzą się tęsknoty za paternalistycznym państwem z autorytarną władzą, która ,zaprowadziłaby porządek". Nic dziwnego, że historycy i politologowie analizujący współczesną sytuację, dopatrują się pewnych analogii z okresem międzywojennym. Zdaniem Harolda Jamesa przykłady Trzeciej Rzeszy czy stalinowskiej Rosji pokazują, iż „odejście od rynku na rzecz kontroli przez państwo nierzadko prowadziło w kierunku dyktatury politycznej”" ${ }^{\prime 6}$. Faszyzm i bolszewizm były przecież politycznie bliskimi sobie reakcjami przeciw globalizacji. Scenariusza załamania się demokracji wraz z krachem globalizacji i powrotem do protekcjonizmu nie wyklucza wielu uczonych. John Saul w książce The Collaps of Globalism również przewiduje pojawienie się neonacjonalizmu, a nawet nastanie okresu przemocy (czego zapowiedzią był 11 września 2001 r.) ${ }^{68}$.

Nawet jeśli uzna się te porównania do sytuacji z lat 30. XX wieku za zbyt pospieszne, to trudno zaprzeczyć, że od przełomu wieków nie zanotowano na świecie postępu procesów demokratyzacji. Jak podaje „The Freedom House Survey”69, w 2014 r. liczba państw „częściowo wolnych” (59) i „pozbawionych wolności" (50) wzrosła w porównaniu do $2000 \mathrm{r}$. Warto zaznaczyć, że w owych 50 państwach zniewolonych żyje aż 2,6 mld ludzi, tj. 36 proc. ludności świata. Aż połowa tej liczby to mieszkańcy Chin. Trzeba tu dodać, że powodów do optymizmu nie daje ani załamanie się procesu demokratyzacji w kilku krajach basenu Morza Śródziemnego zapoczątkowane ,arabską wiosną”, ani umacnianie się dyktatury w Rosji i niektórych państwach postradzieckich. Wobec pluralizmu czynników sprzyjających demokratyzacji i jej „odpływowi”, trudno ten wyraźny kryzys demokracji składać wyłącznie na karb deglobalizacji. Niemniej niewątpliwie koincydencja jednego $\mathrm{z}$ drugim jest trudna.

Jeśli, tak jak autor Centesimus annus - „doceniamy demokrację”, jeśli mimo wszystko zależy nam na naprawie tego „najgorszego z możliwych” ustroju, war-

${ }^{66}$ U. Di FABIO, Berlin ist nicht Weimar, „Frankfurter Allgemeine Zeitung“ 27 września 2018 (nr 225).

${ }^{67}$ H. JAMES, Koniec globalizacji, s. 266.

${ }^{68}$ Por. J.R. SAUL, Globalizacja dobiegła końca, „Europa” (dodatek do „Dziennika”) 28 października 2006.

${ }^{69}$ Por. Freedom in the World, The Freedom House Survey 2016, www.freedomhouse.org, podaję za: W. BERGSDORF, Über die Zukunft. 
to uświadomić sobie, jakie wyzwania stoją dziś przed demokracją. Ogólnie rzecz biorąc, podstawowym jej problemem jest daleko idąca ślepota co do przyszłości. Ze względu na swą krótkowzroczność - sięga wzrokiem jedynie do najbliższych wyborów. Tymczasem polityczni przywódcy muszą się mierzyć z zadaniami perspektywicznymi i umieć dla nich pozyskać akceptację społeczną ${ }^{70}$.

Poza tym warto przypomnieć, że choć cały czas była tu mowa o demokracji $\mathrm{w}$ różnych kontekstach, zwłaszcza w relacji do wolnego rynku, to mówienie o samej demokracji, w oderwaniu od państwa prawa i praw człowieka, wypacza rzeczywistość. Do tej Trójcy dodaje się niekiedy dobrze funkcjonujące społeczeństwo obywatelskie, kulturę polityczną i właśnie gospodarkę rynkową. W każdym razie formalne reguły demokratyczne bez zakotwiczenia państwowoprawnego, a także aksjologicznego, poniekąd są zawieszone w próżni.

Przedmiotem troski w warunkach deglobalizacji musi być zatem nie tyle sama demokracja, ale demokratyczne państwo prawa. Właśnie takie ujęcie jest charakterystyczne dla nauczania społecznego Kościoła. Już w 1987 r. - w Sollicitudo rei socialis Jan Paweł II podkreślał znaczenie wolnych od korupcji struktur demokratycznego państwa prawa dla rozwoju „całego człowieka i wszystkich ludzi”. Domagał się zatem „reformy niektórych niesprawiedliwych struktur, a zwłaszcza własnych instytucji politycznych, aby zastąpić rządy zdeprawowane, dyktatorskie czy autorytarne rządami demokratycznymi i dopuszczającymi uczestnictwo" (SRS 44). Przekonanie, że dobrze funkcjonujące państwo prawa, gwarantujące przestrzeganie praw człowieka i demokratyczną partycypację jest w gruncie rzeczy kluczem rozwoju, znajdujemy w młodszej o 22 lata encyklice Caritas in veritate. Benedykt XVI sugeruje zatem, aby w ramach pomocy rozwojowej „wspierać konsolidację systemów konstytucyjnych, prawnych i administracyjnych w krajach, które nie cieszą się jeszcze tymi dobrami. Obok pomocy ekonomicznej, powinna być ofiarowana ta, która ma na względzie umocnienie gwarancji państwa prawa" (CIV 41).

Wreszcie trzeba na końcu przynajmniej wspomnieć o kwestii absolutnie fundamentalnej. Została ona dobitnie wyartykułowana w Centesimus annus: „Historia uczy, że demokracja bez wartości łatwo się przemienia w jawny lub zakamuflowany totalitaryzm" (CA 46). Ten często przywoływany, ale i nadużywany cytat wymagałby osobnego komentarza. Być może właśnie zapoznanie owych wartości jest głównym powodem obecnych kłopotów liberalnej demokracji.

\footnotetext{
${ }^{70}$ Przykładową listę tych zadań sporządził Wolfgang Bergsdorf. Por. tamże, s. 11-12.
} 


\section{BIBLIOGRAFIA}

Antoszewski A.: [wypowiedź nt.] Demokracja i kryzys, „Zarządzanie Publiczne” 2011, nr 16-17 (2-3), s. 101-104; 115-116.

BARBER B.R.: Globalny dżin, „Gazeta Wyborcza” 1-2 lipca 2000.

BEDNARSKI M.: Czas pracy w polskiej gospodarce. Ewolucja, jej przyczyny i konsekwencje zmian, w: Ekonomia jest piękna? Księga dedykowana Profesorowi Jerzemu Wilkinowi, red. Ł. Hardt, D. Milczarek-Andrzejewska, Warszawa: Wydawnictwo Naukowe Scholar 2015, s. 139-152.

BENEDYKT XVI: Encyklika Caritas in veritate, 2009.

BERGSDORF W.: Über die Zukunft der Demokratie, Köln: J.P. Bachem Medien 2017 („Kirche und Gesellschaft" Nr. 437).

Brakel A.: Nicht so simpel! Francis Fukuyamas „Ende der Geschichte”, „Die Politische Meinung" 2017, z. 547, s. 61-65.

Bunt mas czy kryzys elit?, red. A. Dylus, S. Sowiński, Wrocław: Wydawnictwo TUM Wrocławskiej Księgarni Archidiecezjalnej 2018.

Crouch C.: Postdemokratie, Frankfurt a. M.: Suhrkamp 2008.

DAHRENDORF R.: Keiner fragt, was mit den Managermillionen geschieht, rozm. P. Bahners, A. Cammann, „Frankfurter Allgemeine Zeitung” 10 października 2008.

Delsol Ch.: „Populizm” jako protest wobec nadmiernego uniwersalizmu i obrona zakorzenienia, „Chrześcijaństwo - Świat - Polityka” 2017, nr 21, s. 94-103.

Di FABIO U.: Berlin ist nicht Weimar, „Frankfurter Allgemeine Zeitung“ 27 września 2018 (nr 225).

Di FABio U.: Kein Oswald Spengler. Samuel Huntington und der „Clash of Civilisations“, „Die Politische Meinung“ 2017, z. 547, s. 46-55.

Die fragile Demokratie - The Fragility of Democracy, Hrsg. A. Rauscher, Berlin: Duncker \& Humblot 2007.

Die verstimmte Demokratie. Moderne Volksherrschaft zwischen Aufbruch und Frustration, Hrsg. S. Braun, A. Geisler, Wiesbaden: VS Verlag für Sozialwissenschaften 2012.

DyLus A.: Globalny rynek i jego granice, Warszawa: Centrum im. Adama Smitha \& Instytut Politologii UKSW 2001.

DYLus A.: Gospodarka w perspektywie etycznej i religijnej, Warszawa: Wydawnictwo Naukowe UKSW 2016.

DYLus A.: Koniunkcja demokracji i gospodarki? Perspektywa „Centesimus annus”, „Chrześcijaństwo - Świat - Polityka” 2017, nr 21, s.76-93.

DyLus A.: Patriotyzm gospodarczy. Wielowymiarowość i ambiwalencja, „Społeczeństwo” 2018, nr 1, s. 29-55.

DYLUS A.: Polityka w perspektywie etycznej i religijnej, Warszawa: Wydawnictwo UKSW 2016.

FRANCISZEK: Adhortacja Evangelii Gaudium, 2013.

Freedom in the World, The Freedom House Survey 2016, www.freedomhouse.org

FrÜHBAUER J.: Wirtschaftsdemokratie. Sichtung eines programmatischen Begriffs, Köln: J.P. Bachem Medien 2013 (,Kirche und Gesellschaft“ Nr. 400).

FunuYama F.: The End of History and the Last Man, New York: Free Press 1992.

Gabriel I.: Erosion der Demokratie? Eine Problemanzeige, Köln: J.P. Bachem Medien 2012 (,Kirche und Gesellschaft“ Nr. 394).

Globalisierung und Demokratie, Hrsg. A. Habisch, M. Hartmann, S. Schmidt, J. Wieland, Münster-Hamburg-London: LIT 2000.

Globalisierung und Demokratie. Wirtschaft, Recht, Medien, Hrsg. H. Brunkhorst, M. Kettner, Frankfurt a. M.: suhrkamp taschenbuch 2000. 
GuÉHEnNo J.-M.: Das Ende der Demokratie, München-Zürich: Artemis \& Winkler 1994.

HAusner J.: [wypowiedź nt.] Demokracja i kryzys, „Zarządzanie Publiczne” 2011, nr 16-17(2-3), s. $91-92 ; 112-114$.

Huntington S.: Trzecia fala demokratyzacji, w: Elity, demokracja, wybory, oprac. J. Szczupaczyński, Warszawa: Wydawnictwo Naukowe Scholar 1993, s. 45-85.

JAMES H.: Koniec globalizacji. Czego nauczył nas wielki kryzys?, Warszawa: Wydawnictwo Naukowe Scholar 2010.

JAN PAWE€ II: Adhortacja Ecclesia in America, 1999.

JAN PAWE⿺ II: Encyklika Centesimus annus, 1991.

JAN PAWEE II: Encyklika Evangelium vitae, 1995.

JAN PAWE€ II: Encyklika Sollicitudo rei socialis, 1987.

JAN PAWEe II: Globalizacja będzie tym, co uczynią z niej ludzie, Przemówienie z 27 kwietnia 2001 r. do uczestników sesji plenarnej Papieskiej Akademii Nauk Społecznych, „Więź” 2001/10(516), s. 48-51.

JAROSZYŃSKA M.: Czynniki rozwoju i zagrożenia demokracji w dobie globalizacji, w: Demokracja w dobie globalizacji, t. II: Aspekty teoretyczne, red. M. Domagała, J. Iwanek, Katowice: Wydawnictwo Uniwersytetu Śląskiego 2008, s. 224-235.

KIETLIŃSKI K.: Współczesne wyzwania patriotyzmu gospodarczego, „Społeczeństwo” 2018, nr 2, s. $39-51$.

KoPIEC P.: Chrześcijańska wizja alterglobalizacji. Wkład Światowej Rady Kościołów, „Annales. Etyka w życiu gospodarczym" 20(2017), nr 3, s. 69-80.

KRASNODĘBSKI Z.: Demokracja peryferii, Gdańsk: słowo / obraz terytoria 2003.

KuHN T.S.: Struktura rewolucji naukowych, Warszawa: PWN 1968.

KuŹ M.: Globaliści vs. Lokaliści, „Internetowy Miesięcznik Idei” 3 (57)2015.

LAMmert N.: Visionen in der Politik, rozm. B. Löhmann, „Die Politische Meinung” 2017, z. 547, s. 24-30.

LEGUTKo P.: Rząd ucieka do przodu, „Gość Niedzielny” 28 lutego 2016.

NovaK M.: Duch demokratycznego kapitalizmu, Poznań: Wydawnictwo W drodze 2001.

Nowotarski B.: [wypowiedź nt.] Demokracja i kryzys, „Zarządzanie Publiczne” 2011, nr 16-17 (2-3), s. 104-107; 114-115.

O przyszłość w solidarności i sprawiedliwości, Wspólne Słowo Rady Kościoła Ewangelickiego w Niemczech i Konferencji Episkopatu Niemiec, „Społeczeństwo” 1997, nr 3, s. 399-484.

PAPIESKa RAda Iustitia ET PAX: Kompendium nauki społecznej Kościoła, Kielce: Jedność 2005.

Petersdorff W. von, Plickert Ph.: Die neue alte Angst vor der Globalisierung, „Frankfurter Allgemeine Zeitung“ 20 sierpnia 2016 (nr 194).

PolaK E.: Globalizacja a zagrożenia dla demokracji, w: Demokracja w dobie globalizacji, t. II, Aspekty teoretyczne, red. M. Domagała, J. Iwanek, Katowice: Wydawnictwo Uniwersytetu Śląskiego 2008, s. 140-153.

RYMSZA M.: Nowa kwestia społeczna?, „Więź” 2015/3(661), s. 7-16.

SAUl J.R.: Globalizacja dobiegła końca, „Europa” (dodatek do „Dziennika”) 28 października 2006.

Smolar A.: [wypowiedź nt.] Demokracja i kryzys, „Zarządzanie Publiczne” 2011, nr 16-17(2-3), s. 92-101; 116-121.

Standing G.: Prekariat. Nowa niebezpieczna klasa, Warszawa: PWN 2014.

STAWrowski Z.: Niemoralna demokracja, Kraków: Wydawnictwo Ośrodek Myśli Politycznej, Wyższa Szkoła Europejska im. Józefa Tischnera 2008.

STEINMEIER F.-W.: „Demokratie ist liberal - oder sie ist nicht”, „Frankfurter Allgemeine Zeitung“ 27 września 2018 (nr 225). 
SzTUMSKI J.: Szanse i zagrożenia demokracji w XXI wieku, w: Demokracja w dobie globalizacji, t. II: Aspekty teoretyczne, red. M. Domagała, J. Iwanek, Katowice: Wydawnictwo Uniwersytetu Śląskiego 2008, s. 131-139.

Thielmann U.: Das Ende der Demokratie, „Wirtschaftsdienst“ 12(2011), s. 820-823.

Zwolı́́sKi A.: Dylematy demokracji, Kraków: WAM 2010.

\author{
TRUDNY ZWIĄZEK DEMOKRACJI I WOLNEGO RYNKU \\ W WARUNKACH DEGLOBALIZACJI \\ PERSPEKTYWA KATOLICKIEJ NAUKI SPOŁECZNEJ
}

\begin{abstract}
Streszczenie
W artykule podejmuje się pytanie, czy teza o związku demokracji i wolnego rynku obowiązuje także w warunkach deglobalizacji. Dotychczas koniunkcję autorytarnych reżimów politycznych z liberalnym systemem gospodarczym traktowano jako wyjątki od reguły. Osłabiony dziś związek demokracji i wolnego rynku prezentujemy z ,perspektywy katolickiej nauki społecznej”. W punkcie wyjścia pokazujemy, na czym opiera się przekonanie o współzależności wolnego rynku i demokracji oraz narastanie kryzysu „demokratycznego kapitalizmu”. Następnie omawiamy te związane z globalizacją przemiany gospodarcze, które w konsekwencji osłabiają demokrację. Rezultatem społecznego niezadowolenia ze skutków globalizacji są próby jej zahamowania. Pojawia się jednak pytanie, czy w ogóle jest to możliwe. Dopiero po uchyleniu tej wątpliwości następuje charakterystyka symptomów deglobalizacji. Jeśli gospodarczą globalizację cechuje maksimum rynkowej wolności, to z deglobalizacją wiążemy jej ograniczenie. Rozważania zamyka próba ustalenia, czy to osłabienie rynkowej wolności przekłada się na kondycję demokracji.
\end{abstract}

Słowa kluczowe: demokracja; wolny rynek; kapitalizm; globalizacja; deglobalizacja; katolicka nauka społeczna

\title{
THE COMPLICATED RELATIONSHIP BETWEEN DEMOCRACY AND FREE MARKET IN DEGLOBALIZATION THE CATHOLIC CHURCH SOCIAL DOCTRINE PERSPECTIVE
}

\section{Su m m ary}

The aim of the paper is to address the question of the relationship between democracy and free market in the framework of deglobalization. So far, the relationship between the authoritarian regimes and liberal economy system has been regarded as the exception to the rule. The weakening now relationship between democracy and free market is presented in this paper from the perspective of the Catholic Church Social Doctrine. At the beginning, the basis of the relationship between free market and democracy and the crisis of the "democratic capitalism" are depicted. The economic changes connected with globalization that undermine the democracy are also discussed. The social discontent caused by globalization results in the attempts to hinder this process. There is 
a question, though, whether it is possible to do it. Then, the characteristics of deglobalization symptoms is given. If economic globalization is characterized by the maximum of market freedom so deglobalizaton can be connected with its constraint. At the end, it is considered whether the weakening of free market has an impact on the condition of political democracy.

Key words: democracy; free market; capitalism; globalization; deglobalization; Catholic Church Social Doctrine 